\title{
THE ADAPTATION OF THE QUESTIONNAIRE POSITIVE AND DESTRUCTIVE FAMILY
}

\author{
I lona Skuja, Aleksejs Vorobjovs, Larisa Abelite \\ Daugavpils University, Daugavpils, Latvia \\ E-mail: ilona.skuja@inbox.Iv
}

\begin{abstract}
In order to be able to correct the asocial behaviour of adolescents, several factors that can have POSITIVE AND DESTRUCTIVE FAMILY an effect on the issue must be understood, these being biological, social, and psychological, as well as understanding the context of the situation itself. Various methods were used to research valuable adolescent family environments, including the questionnaire entitled Positive and Destructive Family, which was developed by Russian authors (Опросник "Конструктивно-деструктивная семья" (КДС), Эйдемиллер, Юстиикис). Since this methodology was not available to researchers in Latvian, the first step to be taken was to adapt this method to the cultural environment of Latvia. (The author's consent has been received for the use of the questionnaire in scientific work.) The adaptation of the method allows the following steps to be implemented (Hambleton \& Patsula, 1998; 1999; 2000; Van de Vijver \& Hambleton, 1996): the translation and backward translation of questionnaire observing the context of the cultural environment; empirical verification of the translated questionnaire, thereby establishing its reliability and validity in accordance with the psychometric indicators used to provide a validity check on the factors illustrated in the source survey; the administration of the survey in the new cultural environment; documentation showing the adaptation of the questionnaire and the development of the interpretation of the survey's values. To date, only some of the aforementioned steps have been implemented and presented. Respondents from sixty families participated in the survey (all of whom were aged in group of 31-68, and who included 42 women and eighteen men). The survey consists of twenty statements to which respondents will reply either positively or negatively (this being the dichotomy scale). Further tasks are related to the complete adaptation and application there of in population surveys in Latvia. Another method for family study that has been adapted in Latvia provides more extensive opportunity for further empirical studies, and will also provide a useful set of instruments for practitioners in psychology.
\end{abstract}

Key words: adolescent deviance, dysfunctional family, questionnaire adaptation.

\section{I ntroduction}

In Latvia, the issue of juvenile delinquency is still pending. The fact that adolescents often fail to change their behaviour and, instead continue to repeat their offences, should be considered alarming. Deviant behaviour in full may be understood only if several factors, what have an effect on this issue, must be understood. These factors being biological, social, psychological, as well as understanding the context of the situation in which such an offence occurs. By involving an indi- 
vidual in a social environment, a gradual process of socialisation occurs. The most intensive process of socialisation occurs in childhood, and the family is considered to be the primary socialiser. The notion of socialisation is often used as a synonym for parenting, teaching, etc. If an individual experiences any adaptation issues, other members of the family must, to some extent, adjust themselves to that individual. Any attempts to adjust may require considerable efforts from each individual and from the family in general, and can sometimes even lead to the family's break-down or dysfunction. For in-depth research on a family's failure to function, a survey, available to researchers only in the Russian language has been chosen. Therefore, the purpose of this research shall be an adaptation of the method shown to the cultural environment of Latvia. Any adapted instrument provides an opportunity for new surveys. Any survey that provides answers to causes for unsuccessful socialisation may help to develop measures for the 'resocialisation' of adolescents and other preventive measures for the elimination of behavioural disorders in adolescents.

\section{The Family as a Research Object in Psychology}

In society there are various types of families that differ from one another in various factors, including the number of people they contain, their structure, their location and the way they live, their gender, socioeconomic level, distribution of roles, and numerous of other factors. This restricts unification and quick, and easy understanding of the notion of "family" because there is no unified concept of a family and its essence. A family may be researched in various ways, both as a historically social unit, a social group, the subject of mutual relations (cooperation), and as a unified system (Karpova, 2000). A cluster of united and behaviourally coordinated family members will be useful when it comes to considering them as an open, dynamic and self-regulating social system, one which includes a programme for optimum functioning developed through social practice (Papp, 1984). Supporters of the systemic approach consider that each conflict or crisis situation in the family has a destructive effect on any member involved in that situation. Similar processes may also be observed in opposing situations, no matter which member of the family changes their behaviour in a positive manner, because, as a result of such change, the entire family system will have to change as well (Bowen, 1978). Just like other social systems, the family as a system includes a programme that has been developed through social experience, which ensures the optimum functioning of the system, i.e. its purposeful and stable functioning, as well as specific mechanisms and stereotypes for verbal and non-verbal behaviour which, with reference to influences, can turn away from the initial purposeful cooperation of family members and the correct operation of the system, and return it to its optimum regimen (Karpova, 2000).

Family researchers who attempt to define a standard for a functioning family usually adhere to any of the following positions:

- They create their own opinions of what kind of relationship should exist between family members and what it shall not be;

- The promote a principal requirement for the functioning of a favourable family (such as, for instance, what material or moral conditions are required for each individual family member);

- They know what a family cannot be;

- They trust to the client and help that client to avoid the things that might be interfering with family life (Эйдемиллер, Юстицкис, 1999). Three types of dysfunction are distinguished in social work:

1. A lack of necessary function. Among those who belong to the system (the system being the family), there is lack of interaction (such as, for instance, in a non-complete family).

2. Incorrect function. The family fails to fulfil the tasks that are entrusted to it, thereby functioning incorrectly (such as, for instance, becoming an isolated group in its vicinity; within this, children are unable to free themselves from their dependency on their parents and remain nonviable as functioning individuals). 
3. A conflict of functions. The system (the family) is unable to function according to its purpose because the most significant members of the family act against each otherfailing to cooperate, refusing to collaborate, and behaving in a dysfunctional manner. Internal family conflict occurs, as a result of which the family functions incorrectly.

A dysfunctional family is labelled as a problem system, and it is in society's interests to correct any dysfunctional social system, so that it can begin to function properly. Psychologists pay more attention to researching family structure, which includes the composition of the family and the unity of its mutual relationships. To analyse a family structure means establishing the way in which its functions as a social group are being implemented. Any broken, damaged, or destructive structure is described by signs which encumber the implementation of the functions (Karpova, 2000).

\section{The Influence of the Adolescent on Family Functioning}

The structure and functions of the family change depending on which stage of the life cycle it is passing through (Karpova, 2000). The phases for family life have been researched by numerous scientists (including K. Rogers, R. Hill, etc.). However, E Duvall's approach is often used, in which the principal property that separates one phase of the family from another is children-their existence or lack thereof, and their age. The significance of the family in parenting cannot be overestimated. However, when analysing the family as a system, we may conclude a feedback as well, in terms of a child's influence on its parents and the family in general (Абабков, 1999). Various relationships exist simultaneously within the family, including relationships between the parents themselves, and between the parents and their children. A crisis situation in the family often occurs when children become adolescents. At this transitional stage, the restructuring of the mutual relationship among members of the family, any changes in composition of this relationship, etc. must occur (Тайсон, Тайсон, 1998). One diagnostic indication that a family is functioning properly is its adaptation, which reflects how flexible or vice versa (how rigid) the family structure is, how able it is to adjust to different internal or external stressors (Эйдемиллер, Юстицкис, 1999). (Children becoming adolescents should be considered as being a stress point for any family system.) The following parameters are used for the adaptation of a family: leadership in the family, discipline, leading roles, and existing family rules. Since the family is a self-regulating system and every change is based upon changes in the system, we may consider that an individual's behaviour is determined by the rules that are utilised in the family's system of operation rather than through individual motivation and needs (Черников, 1997). If the family system is unable to adapt to the new situation, then fixation and regression occurs, which causes the family to become dysfunctional (Karpova, 2000). Other authors analyse disorders of family functioning either as 1) a disorder at the subject level, 2) disorder in the system, 3) inter-group or inter-systemic disorder. One significant indication of the family's proper functioning should be its unity or cohesion (Minuchin, 1985; Olson, 1986; Reiss, 1982). Increased distance between family members provides evidence of a conflicting, negative, or otherwise emotionally-alienated relationship (Gehring \& Schultheiss, 1986; Gerber \& Kaswan, 1971; Russel, 1980). In a dysfunctional family, communication is usually encumbered (Jackson, 1968; Haley, 1963). Furthermore, it is not only verbal or non-verbal communication that is of primary importance, metacommunication is also vital: thoughts, the views of an individual, and the individual's attitude towards other family members and the family in general (Russell, 1980). Systems that have negative self-evaluation (showing a lack of faith in its own abilities to solve the situation) experience encumbered functioning and usually seem hopeless (Черников, 2001).

Summing up theoretics, a hypothesis may be set out in which the result of the adaptation of the family to a large extent affects whether an adolescent's behaviour will become socially adequate. In turn, in order to be able to assess the ability of parents to be able to react positively to their child's deviance, the questionnaire Positive and Destructive Family (Опросник «Конструктивнодеструктивная семья» (КДС), Эйдемиллер, Юстицкис) was chosen as one of the research methods. Since this methodology was not available to researchers in Latvian, the first step was to adapt this survey to the cultural environment of Latvia. (The author's consent has been received for the use of the survey in scientific work.) The adaptation of the method provides for the implementation of the following steps: the translation and backward translation of the survey observing the context of 
the cultural environment; empirical verification of the translated survey, establishing its reliability and validity in accordance with the psychometric indicators used to provide a validity check on the factors illustrated in the source survey; the administration of the survey in the new cultural environment; documentation of the adaptation process for the survey and development of the interpretation of the survey's values (Hambleton \& Patsula, 1999; 2001).

To date, only some of the aforementioned steps have been implemented and presented.

\section{Methododology of Research}

The authors of the questionnaire Positive and Destructive Family are the Russian scientists, E. G. Eidemiller and V. V. Justickis (Эйдемиллер, Юстицкис, 1999). The authors of this instrument note that the survey has not been aimed at establishing whether the specific family is dysfunctional or not. The purpose of this survey will be to research the so-called problem family; namely a family in which any of its members are a cause of concern to the others. Within the frame of this survey, families were selected in which adolescents have been diagnosed as exhibiting deviant behaviour (by breaking the law). A control group for families in which the behaviour of adolescents is not disturbed cannot be formed because all of the questions in the survey require an assessment of attitudes towards the member of the family who has given rise to concern. Therefore, if an adolescent behaves within the family in a socially adequate manner, asking these questions of parents would be meaningless. This includes, for instance, the fifth statement - whatever we do with him/her, he/ she becomes worse; or the sixth statement - people around us consider me to be responsible for what happens to him/her; or the seventh statement - he/she often escapes and I do not know what happens to him/her. Therefore, by using this questionnaire, it may be able to assess the level of dysfunction within a family, or the conflict it is experiencing in a crisis situation, as well as being able to understand the limited abilities of the family when it comes to solving problems in a positive manner. The questions in the survey have been formulated in order to allow any possible family dysfunction to be assessed according to four significant parameters:

1. Influence. If at least five positive replies are given to questions contained in this section, it suggests deficient parental power or influence in parenting, and the hierarchy between family subsystems is not optimal.

2. Frustration. A parent is disappointed with their child, and the so-called unfulfilled expectations in the mutual child-parent relationship may be observed when reality fails to comply with wishes. At least four positive statements suggest this.

3. Information. At least five positive replies to questions contained in this section suggest insufficient communication.

4. Alienation. This requires at least three positive replies.

If the respondent provides five or more positive answers, the family's functioning in a crisis situation can no longer be considered as being positive. Twelve or more positive statements suggests a significant level of disorder in the family's functioning when the family is unable to solve issues in a positive manner in relation to the child's behaviour.

Respondents from sixty families in which adolescents have committed a crime were able to participate in the survey (the respondents being between the ages of 31-68, of which 42 were women and eighteen were men). Almost all of the respondents were the parents or guardians of adolescents; in three cases these were grandmothers who were ensuring the full care and parenting of children, while in two cases they were guardians.

Questionnaire consists of twenty statements to which respondents shall provide either a positive or negative answer (the dichotomy scale). Neutral position such as "don't know" or "maybe" is allowable for no more than three statements. Respondents are given the instruction that "the survey sheet includes statements that are related to your family member who gives you the most cause for concern".

First of all, questionnaire was translated and backwards translated. This was carried out by independent bilingual translators. The backwards translation was compared to the Russian version and, if necessary, clauses were amended. All respondents were informed of the course of the survey 
and they participated in the survey on a voluntary basis.

Answers were acquired either in small groups or individually during March 2013, with no time limit being set. Initially, the so-called "obvious validity" or face validity was assessed. It was followed by the content validity check by expert method. Furthermore, the invited experts considered that the content of statements in the survey "represents the psychological nature or behavioural unity of the sign to be assessed" (Raščevska, 2005).

\section{Research Results}

Data analysis (the information acquired from the research was processed with the help of the SPSS programme):

Table 1. Case Processing Summary.

\begin{tabular}{cccc}
\hline & & N & $\%$ \\
\hline \multirow{3}{*}{ Cases } & Valid & 60 & 100.0 \\
& Excluded & 0 & 0.00 \\
& Total & 60 & 100.0 \\
\hline
\end{tabular}

a. Listwise deletion based on all variables in the procedure

Table 2. Reliability Statistics No 1.

\begin{tabular}{cc}
\hline Cronbach's Alpha & No of Items \\
\hline 0.718 & 20 \\
\hline
\end{tabular}

A commonly accepted rule of thumb for describing internal consistency using Cronbach's Alpha is as follows (however, a greater number of items in the test can artificially inflate the value of alpha and a sample with a narrow range can deflate it, so this rule of thumb should be used with caution):

\begin{tabular}{cl}
\hline Cronbach's Alpha & Internal consistency \\
\hline$a \geq 0.9$ & Excellent (High-Stakes testing) \\
$0.8 \leq a<0.9$ & Good (Low-Stakes testing) \\
$0.7 \leq a<0.8$ & Acceptable (Surveys) \\
$0.6 \leq a<0.7$ & Questionable \\
$0.5 \leq a<0.6$ & Poor \\
$a<0.5$ & Unacceptable
\end{tabular}

George, D, \& Mallery, P (2003)

Cronbach's Alpha ratio $=0.718$ shall be considered as being high and suggests that questions in the survey are harmonised and congeneric.

Table 3. I Item - Total Statistics.

\begin{tabular}{ccccc}
\hline & $\begin{array}{c}\text { Scale Mean if Item } \\
\text { Deleted }\end{array}$ & $\begin{array}{c}\text { Scale Variance if } \\
\text { Item Deleted }\end{array}$ & $\begin{array}{c}\text { Corrected Item- } \\
\text { Total } \\
\text { Correlation }\end{array}$ & $\begin{array}{c}\text { Cronbach's } \\
\text { Alpha if Item } \\
\text { Deleted }\end{array}$ \\
\hline VAR00001 & 5.7833 & 11.562 & 0.359 & 0.700 \\
VAR00002 & 5.9333 & 11.114 & 0.538 & 0.683 \\
VAR00003 & 5.9667 & 11.694 & 0.360 & 0.700
\end{tabular}




\begin{tabular}{ccccc}
\hline & $\begin{array}{c}\text { Scale Mean if Item } \\
\text { Deleted }\end{array}$ & $\begin{array}{c}\text { Scale Variance if } \\
\text { Item Deleted }\end{array}$ & $\begin{array}{c}\text { Corrected Item- } \\
\text { Total } \\
\text { Correlation }\end{array}$ & $\begin{array}{c}\text { Cronbach's } \\
\text { Alpha if Item } \\
\text { Deleted }\end{array}$ \\
\hline VAR00004 & 6.0833 & 12.417 & 0.274 & 0.715 \\
VAR00005 & 5.7833 & 11.901 & 0.256 & 0.710 \\
VAR00006 & 5.9500 & 12.184 & 0.196 & 0.715 \\
VAR00007 & 5.9667 & 11.592 & 0.394 & 0.697 \\
VAR00008 & 6.1000 & 12.397 & 0.292 & 0.714 \\
VAR00009 & 5.7833 & 11.596 & 0.348 & 0.701 \\
VAR00010 & 6.0000 & 13.254 & -0.125 & 0.741 \\
VAR00011 & 5.7667 & 11.538 & 0.366 & 0.699 \\
VAR00012 & 6.0167 & 11.576 & 0.431 & 0.694 \\
VAR00013 & 5.8500 & 11.486 & 0.390 & 0.697 \\
VAR00014 & 6.0333 & 12.880 & -0.005 & 0.730 \\
VAR00015 & 5.9500 & 11.540 & 0.404 & 0.696 \\
VAR00016 & 6.1167 & 12.512 & 0.259 & 0.716 \\
VAR00017 & 5.9667 & 11.490 & 0.428 & 0.694 \\
VAR00018 & 6.0167 & 12.729 & 0.241 & 0.727 \\
VAR00019 & 6.0000 & 11.593 & 0.413 & 0.696 \\
VAR00020 & 6.0000 & 11.932 & 0.297 & 0.706 \\
\hline
\end{tabular}

The indication of overall internal harmonisation was largely influenced by questions ten and fourteen. Cronbach's alpha ratio increases without these questions.

Table 4. Reliability Statistics No 2.

\begin{tabular}{cc} 
Cronbach's Alpha & No of Items \\
\hline 0.755 & 18 \\
\hline
\end{tabular}

Retest reliability check carried out in the selection $n=30$ after one month, obtaining Cronbach's Alpha -0.701.

Positive family functioning is observed in only nineteen respondents, which is $31.6 \%$ of the total selection $(n=60)$. Five respondents have provided positive replies to more than twelve answers, suggesting the highest degree of dysfunctional response to the behavioural disorder of the child. A total of $25 \%$ of the selection or fifteen respondents demonstrated alienation or separation from their child in their replies. In 37 cases or $61.6 \%$ of the total figure, results demonstrate the reduced or insufficient ability of parents to correct their child's behaviour, while in 35 cases or $50.83 \%$ there was an insufficient exchange of information within the family system, and in $16.6 \%$ there was frustration. However, it must be noted that this was a self-evaluation survey, one in which the results represent the opinion of the parents themselves in terms of their relationship with their children, and their ability to influence the behaviour of their child, etc. rather than objective reality.

\section{Discussion}

Although all respondents in this survey were selected from dysfunctional families that exhibited the same sign - an adolescent with a behavioural disorder who has committed an offence - after deeper research certain parameters were acquired which show similarities, although they were not 
identical. Since the behaviour of adolescents requires correction, it is important to ensure the optimal functioning of the family as a system. As may be observed from the acquired results, only about a Volume 7, 2013 third of the families that are involved in stress situations are able to treat the problem positively. Literature also suggests the notion of a latent family functioning disorder. This is a disorder for which compensation may be provided in daily life, while in critical moments it may cause hindrances in optimum functioning, and in critical moments the family is unable to mobilise its internal resources. As a result, a psychotraumatic family environment is formed which results in overall dissatisfaction, alarm, a sense of guilt, somatic manifestations, etc. for the family (Эйдемиллер Э Г, Юстицкис В, $1999 ; 2002)$. Therefore, we may conclude that an adolescent's deviance may not only be a stressor for family functioning (its cause), but also an indicator, providing evidence of a previously existing, albeit latent, family dysfunction (the consequence). The family as a system usually develops a ready-to-apply behavioural model, although when the child achieves adolescence, the peculiarities of their respective age and the specific needs of an individual who is related to them should be taken into account, while former family functioning models or strategies must be adjusted according to the new situation (Terkelsen, 1980).

\section{Conclusion}

The adaptation of questionnaire Positive and destructive family is part of a more extensive survey. Since the results that have been obtained from the Latvian version of the survey comply with the psychometric indices in the source survey, further tasks should be related to the complete adaptation of the method among a more extensive selection and the application of this for research amongst the Latvian population. Currently, Latvian legislation provides a psychosocial correction programme for each adolescent who has committed a crime. However, as we know, attempts to correct a child's behaviour without changing the closest environment - their family - will have only a limited effect. Another family research method that has been adapted in Latvia provides more extensive opportunities for further empirical research in Latvia and is useful set of instruments for practitioners in psychology.

\section{References}

Bowen, M. (1978). Family therapy in clinical practice. New York: Rowan \& Littlefield Publishers, Inc.

Gehring, T. M., Schultheiss, R. B. (1987). Spatial representation and assessment of family relationships. The American Journal of Family Therapy, 15, 261-264.

Gerber, G. L. (1973). Psychological distance in the family as schematized by families of normal, disturbed, and learning - problem children. Journal of Consulting and Clinical Psychology, 40, 139-147.

George, D., Mallery, P. (2003). SPSS for Windows step by step: A simple guide and reference. 11.0 update (4th ed.). Boston: Allyn \& Bacon.

Haley, J. (1976). Problem solving therapy. San Francisco: Jossey-Bass.

Hambleton, R. K. (2001). The next generation of the ITC Test Translation and Adaptation Guidelines. European Journal of Psychological Assessment, 17, 164-172.

Hambleton, R. K., Patsula, L. (1998). Adapting tests for use in multiple languages and cultures. Social Indicators Research.

Hambleton, R. K., \& Patsula, L. (1999). Increasing the validity of adapted tests: Myths to be avoided and guidelines for improving test adaptation practices. Journal of Applied Testing Technology, 1, 1-30.

Hill, J. (2002). Biological, psychological and social processes in the conduct disorders. Journal of Child Psychology and Psychiatry, 43, 1, 133-164.

Jackson, D. (1965). The study of the family. Family Process, 4, 1, 1-20.

Karpova, A. (2006). Gimenes psihologija. Rīga: Raka. 
Minuchin, S., Fishman H. S. (1981). Family therapy techniques. Cambridge, MA: Harward University Press.

Olson, D., (1985). Faces-3. Family Adaptability and Cohesion Evaluation Scale. Family Social Science. University of Minnesota.

Papp, D. S.(1984). Contemporary international relations: Frameworks for understanding. Macmillan; New York.

Raščevska, R. (2005). Psihologisko testu un aptauju konstruēšana un adaptācija. Izdevniecība RaKa.

Reiss, D. E. (1981). The Family's construction of reality. Cambridge, Mass: Harward University press.

Rogers, C. R.(1959). A theory of therapy, personality and interpersonal relationshipe, as developed in the client-centred tramework. In: Koch S. Psychology the study of a science. New York: Mc Graw-Hill.

Van de Vijver, F. J. R., Hambleton, R. K. (1996). Translating tests: Some practical guidelines. European Psychologist, 1, 89-99.

Абабков, В. А., Перре М., Плапшерел Б. (1999). Систематическое исследование семейного стресса и копинга. Обозрение психиатрии и медицинской психологии им. В. М. Бехтерева.

Тайсон, Р, Тайсон Ф. (1999). Психоаналитические теории развития (Пер. с англ.) Екатеринбург: Деловая книга.

Черников, А. В. (2001). Системная семейная терапия: Интегративная модель диагностики. Изд. 3-е, испр. и доп. М.: Независимая фирма "Класс" (Библиотека психологии и психотерапии, вып. 97).

Эйдемиллер, Э. Г. (1996). Методы семейной диагностики и психотерапии. Москва.

Эйдемиллер, Э. Г., Юстицкис, В. В. (1999). Психология и психотерапия семьи. Санкт-Петербург.: Питер.

Advised by Vincentas Lamanauskas, University of Siauliai, Lithuania

Received: July 17, 2013

Accepted: September 15, 2013

\begin{tabular}{cl}
\hline Ilona Skuja & Mag.psych., Departament of Psychology, Daugavpils University, \\
& Parades 1, LV- 5400, Daugavpils, Latvia. \\
& E-mail: ilona.skuja@inbox.lv \\
& Website: http://www.du.Iv \\
\hline Aleksejs Vorobjovs & Dr. habil. paed., Dr. habil. Psych., Professor, Department of Psychology, Daugavpils \\
& $\begin{array}{l}\text { University, Daugavpils, Latvia. } \\
\text { E-mail: aleksejs.vorobjovs@du.lv }\end{array}$ \\
\hline Larisa Abelite & Mag.psych., Departament of Psychology, Daugavpils University, Daugavpils, Latvia. \\
& E-mail: larisa.abelite@riga.lv \\
\hline
\end{tabular}

